\title{
ANALISIS PENGGUNAAN ANTIBIOTIK DI RUANG BEDAH RUMAH SAKIT UMUM DAERAH DR. H. ABDUL MOLOEK PROVINSI LAMPUNG DENGAN METODE DEFINED DAILY DOSE PERIODE JANUARI-MARET TAHUN 2018
}

\author{
Hidayat $^{1}$, Neno Fitriyani Hasbie ${ }^{2}$, Galih Adityadarma ${ }^{3^{*}}$ \\ ${ }^{1,2}$ Fakultas Kedokteran, Universitas Malahayati, Lampung \\ ${ }^{3}$ Mahasiswa Kedokteran, Fakultas Kedokteran, Universitas Malahayati, Lampung \\ Email korespondensi: galih123@gmail.com
}

\section{ABSTRACT: ANALYSIS OF THE USE OF ANTIBIOTICS IN THE SURGERY ROOM OF THE REGIONAL GENERAL HOSPITAL H. ABDUL MOLOEK PROVINCE LAMPUNG WITH DEFINED DAILY DOSE METHOD OF JANUARY-MARCHPERIOD 2018}

Background : Antibiotics are chemicals produced by fungi and bacteria, which have the property of killing or inhibiting the growth of germs. In developed countries 13-37\% of all patients hospitalized receive antibiotics either alone or in combination, while in developing countries $30-80 \%$ of patients hospitalized receive antibiotics and irrational use of antibiotics is very common. both in developed and developing countries. Germicidal resistance to antibiotics, especially multi-drug resistance, is a problem that is difficult to overcome in the treatment of patients. This study aims to evaluate the use of antibiotics with the Defined Daily Dose method in patients in the surgical room of Dr. $\mathrm{H}$. Abdul Moloek, Lampung Province.

Method : This type of research is descriptive using a cross-sectional approach. The sample in this study were 72 medical records in the operating room, data were obtained from RSUD Dr. H. Abdul Moloek, Lampung Province and carried out by assessing Defined Daily Dose.

Results: The frequency distribution of patients in the male operating room who received antibiotic therapy was 72 patients with the largest age range being 18-30 years. The results of the study in the men's surgery room at the $\mathrm{Dr}, \mathrm{H}$. Abdul Moloek Regional Hospital showed that quantitatively the use of antibiotics with the Defined Daily Dose category was 570.5 with the antibiotic ceftriaxone (523) being the highest. And for DDD / 100 days of hospitalization as much as 112.6 with the highest ceftriaxone was 104.6 DDD / 100 days of hospitalization.

Conclusion: It shows that quantitatively the use of antibiotics is most often prescribed in the Men's Surgery room at RSUD DR. H. Abdul Moeloek, Lampung Province, was Seftriaxone with 104.6 DDD / 100 days of hospitalization..

Keywords: Analysis, Antibiotics, Method Defined Daily Dose. 


\section{INTISARI: ANALISIS PENGGUNAAN ANTIBIOTIK DI RUANG BEDAH RUMAH SAKIT UMUM DAERAH DR. H. ABDUL MOLOEK PROVINSI LAMPUNG DENGAN METODE DEFINED DAILY DOSE PERIODE JANUARI-MARET TAHUN 2018}

Latar Belakang: Antibiotik adalah zat-zat kimia yang dihasilkan oleh fungi dan bakteri, yang memiliki khasiat mematikan atau menghambat pertumbuhan kuman. Di negara yang sudah maju 13-37\% dari seluruh penderita yang dirawat di rumah sakit mendapatkan antibiotik baik secara tunggal atau kombinasi, sedangkan di negara berkembang $30-80 \%$ penderita yang dirawat di rumah sakit mendapatkan antibiotik dan penggunaan antibiotik yang tidak rasional sangat banyak dijumpai baik di negara maju maupun berkembang. Resistensi kuman terhadap antibiotik, terlebih lagi multi drug resistance merupakan masalah yang sulit diatasi dalam pengobatan pasien. Penelitian ini bertujuan untuk mengevaluasi penggunaan antibiotik dengan metode Defined Daily Dose pada pasien di Ruang Bedah RSUD Dr. H. Abdul Moloek Provinsi Lampung.

Metode: Jenis penelitian ini adalah deskriptif dengan menggunakan pendekatan cross-sectional. Sampel pada penelitian ini sebanyak 72 catatan rekam medik di ruang bedah, data diperoleh dari RSUD Dr. H. Abdul Moloek Provinsi Lampung dan dilakukan dengan penilaian Defined Daily Dose.

Hasil: Di dapatkan distribusi frekuensi pasien di ruang bedah laki-laki yang menerima terapi antibiotik adalah sebanyak 72 pasien dengan rentang usia yang terbanyak 18-30 tahun. Hasil penelitian di ruang bedah laki-laki di RSUD Dr, H. Abdul Moloek Provinsi Lampung menunjukkan bahwa secara kuantitatif penggunaan antibiotik dengan kategori Defined Daily Dose sebanyak 570,5 dengan antibiotik seftriakson (523) yang paling tinggi. Dan untuk DDD/100 hari rawat sebanyak 112,6 dengan pemberian seftriakson yang paling tinggi sebesar 104,6 DDD/100 hari rawat.

Kesimpulan : Menunjukkan bahwa secara kuantitatif penggunaan antibiotik yang paling banyak di resepkan di ruang Bedah Laki-laki di RSUD DR. H. Abdul Moeloek Provinsi Lampungadalah Seftriakson sebesar 104,6 DDD/100 hari rawat.

Kata kunci : Analisis, Antibiotik, Metode Defined Daily Dose

\section{PENDAHULUAN}

Antibiotik profilaksis bedah adalah penggunaan antibiotik sebelum, selama, dan paling lama 24 jam pasca operasi pada kasus yang secara klinis tidak memperlihatkan tanda infeksi dengan tujuan mencegah terjadinya infeksi luka daerah operasi (Menkes RI, 2015). Infeksi ini dapat menyebabkan ketidakmampuan fungsional, stress, penurunan kualitas hidup pasien dan menimbulkan masalah ekonomi (Ducel et al, 2002).

Antibiotik adalah zat-zat kimia yang dihasilkan oleh fungi dan bakteri, yang memiliki khasiat mematikan atau menghambat pertumbuhan kuman (Tjay dan Rahardja, 2007). Di negara yang sudah maju $13-37 \%$ dari seluruh penderita yang dirawat di rumah sakit mendapatkan antibiotik baik secara tunggal atau kombinasi, sedangkan di negara berkembang $30-80 \%$ penderita yang dirawat di rumah sakit mendapatkan antibiotik dan penggunaan antibiotik yang tidak rasional sangat banyak dijumpai baik di negara maju maupun berkembang. Adapun manfaat penggunaan antibiotik tidak perlu diragukan lagi, akan tetapi penggunaannya yang 
berlebihan akan segera diikuti dengan munculnya kuman kebal antibiotik, sehingga manfaatnya akan berkurang (Brahma Marak and Wahlang 2012).

Resistensi kuman terhadap antibiotik, terlebih lagi multi drug resistance merupakan masalah yang sulit diatasi dalam pengobatan pasien. Hal ini muncul sebagai akibat pemakaian antibiotik yang kurang tepat dosis, macam dan lama pemberian sehingga kuman berubah menjadi resisten untuk itu penggunaan antibiotik perlu dievaluasi (Ding et al. 2016). Evaluasi penggunaan antibiotik dapat melalui evaluasi kuantitatif. Evaluasi kuantitatif penggunaan antibiotik di rumah sakit menggunakan metode Defined Daily Doses (DDD) dimana dengan metode ini akan diperoleh data pemakaian antibiotik yang baku dan dapat dibandingkan dengan tempat lain sesuai standar WHO (Kemenkes, 2011).

Menurut penelitian yang dilakukan oleh Apriliana tahun 2017 mengenai evaluasi rasionalitas penggunaan antibiotik profilaksis di Rumah Sakit Bethesda Yogyakarta menunjukkan peresepan antibiotik profilaksis yang digunakan adalah Ceftriaxone $(65,52 \%)$, Cefotaxime (15,25\%), Cefuroxime $(5,17 \%)$, Cefixime $(1,72 \%)$, Cefoperazone + Sulbactam (6,90\%). Rasionalitas penggunaan antibiotik profilaksis menurut penelitian ini adalah 25 kasus $(43,10 \%)$ rasional dan 33 $(56,90 \%)$ kasus tidak rasional. Permasalahan dari ketidakrasionalan adalah ketidaktepatan pemilihan antibiotik profilaksis $(13,79 \%)$, dosis $(6,90 \%)$ dan waktu pemberian (51,72\%) (Apriliana, 2017). Evaluasi penggunaan antibotik juga dapat dilihat dari terjadinya Drug Related Problems (DRPs) sebagai akibat penggunaan antibiotik yang tidak rasional. DRPs yang terbaru adalah klasifikasi PCNE (Pharmaceutical Care Network Europe) versi V7.0 2016 yang membahas DRPs berdasarkan permasalahan dan penyebab, pada versi ini pembahasan permasalahan terdiri dari tiga domain utama yaitu efektivitas terapi, reaksi obat yang tidak diinginkan dan lainnya. Di Indonesia, penelitian mengenai DRPs penggunaan antibiotik menggunakan klasifikasi PCNE versi ini belum banyak dilakukan termasuk pada penyakit infeksi. Pada hasil penelitian 2015 mengenai DRPs penggunaan antibiotik di suatu rumah sakit di Etiopia terdapat 75,7 $\%$ permasalahan penggunaan antibiotik yang meliputi 29,6 \% membutuhkan penambahan antibiotik, 28,9 \% penggunaan antibiotik yang tidak diperlukan, $28,9 \%$ dosis terlalu rendah, $15,1 \%$ dosis terlalu tinggi, 9,2\% antibiotik tidak efektif, $17 \%$ tidak patuhnya pasien dan DRPs potensial 8,6\% (Lampert et al., 2017; Huri et al., 2014; Yadesa et al., 2015).

\section{METODE}

Penelitian dilaksanakan di Ruang Bedah RSUD DR. H. Abdul Moeloek Provinsi Lampung pada bulan Januari sampai Maret 2018. Penelitian ini termasuk dalam jenis penelitian deskriptif (Crosssectional). Kriteria inklusi pada penelitian ini yaitu : Semua pasien rawat inap di ruang Gelatik RSUD DR. H. Abdul Moeloek periode Januari - Maret 2018 ,Subjek penelitian adalah pasien laki-laki usia $\geq 16$ tahun ,Rekam medik yang lengkap dan jelas terbaca. Yang termasuk kriteria ekslusi pada penelitian ini yaitu : Data rekam medik yang tidak lengkap dan tidak bisa dievaluasi , Pasien rawat inap di ruang gelatik RSUD DR. H. Abdul Moeloek yang tidak mendapatkan 
terapi antibiotik. Analisis yang digunakan untuk menganalisis setiap variabel (terikat atau bebas) yang akan diteliti secara deskriptif. Data yang akan dikategorikan ditampilkan sebagai frekuensi kejadian. Identifikasi data demografi pasien (Jenis kelamin dan usia), serta pola dan jenis penggunaan antibiotik dianalisis secara deskriptif dalam bentuk table dan uraian penjelasan. Identifikasi rasionalitas antibiotik menggunakan metode Defined Daily Dose.Tata cara analisis dengan menggunakan metode Defined Daily Dose yaitu : Identifikasi jenis antibiotik, baik tunggal maupun kombinasi, Identifikasi Defined Daily Dose (DDD), Hitung jumlah kekuatan antibiotik (dalam gram) yang digunakan, Hitung jumlah hari rawat pasien di rawat inap RSUD $\mathrm{H}$. Abdul Moeloek tahun 2018, Hitung nilai DDD/100 patient-days untuk masing-masing jenis antibiotik atau kombinasi antibiotik dengan menggunakan rumus seperti yang tertara dibawah ini : $\mathrm{DDD} / 100$ days = Jumlah gram antibiotik yang digunakan oleh pasien/(Standar WHO dalam Gram) $X$ 100/(Total LOS). Data hasil perhitungan $\mathrm{DDD} / 100$ days diubah dalam bentuk persentase kemudian dikumulatifkan.

\section{HASIL DAN PEMBAHASAN}

Analisis univariat dilakukan untuk karakteristik subjek penelitian meliputi usia, lama rawat inap, kuantitas penggunaan antibiotik profilaksis. Dari 72 catatan rekam medik di Ruang Bedah Gelatik RSUD Dr. H. Abdul Moeloek Provinsi Lampung subjek penelitian terdiri dari 72 berjenis kelamin laki-laki.
Tabel 1 Distribusi pasien yang diberi antibiotik berdasarkan usia

\begin{tabular}{ccc}
$\begin{array}{c}\text { Usia } \\
\text { (tahun) }\end{array}$ & $\begin{array}{c}\text { Jumlah } \\
(\mathrm{N})\end{array}$ & $\begin{array}{c}\text { Persentase } \\
(\%)\end{array}$ \\
\cline { 1 - 2 } $18-30$ & 24 & 33,3 \\
$31-45$ & 23 & 31,9 \\
$46-60$ & 13 & 18,1 \\
$\geq 61$ & 12 & 16,7 \\
\hline Total & 72 & 100 \\
\hline
\end{tabular}

Kategori usia tersebut dapat dilihat bahwa rentang usia 18-30 tahun adalah rentang usia pasien terbanyak yang ditemukan yaitu sebesar 24 pasien ( 33,3\% ), sedangkan pada rentang usia 31-45 tahun terdapat 23 pasien ( $31,9 \%)$, 46-60 terdapat 13 pasien $(18,1 \%)$ dan $\geq 61$ tahun terdapat 12 pasien ( $16,7 \%)$.

\section{Tabel 2 Distribusi frekuensi lama rawat inap}

\begin{tabular}{ccc}
\hline (Hari) & Jumlah (N) & Persentasi (\%) \\
\hline $1-5$ & 29 & 40,3 \\
$6-10$ & 31 & 43,1 \\
$11-15$ & 8 & 11,1 \\
$16-20$ & 4 & 5,6 \\
\hline Total & 72 & 100
\end{tabular}

Lama rawat hari inap terbanyak yaitu (6-10 hari) dengan jumlah pasien 31 (43.1\%), pada lama hari rawat inap dengan kategori (1-5 hari) dengan jumlah pasien 29 (40,3\%), kategori 11-15 hari dengan jumlah pasien $8(11,1 \%)$, dan kategori 16-20 hari dengan $4(5,6 \%)$. 
Tabel 3 Distribusi frekuensi jenis antibiotik yang diresepkan

\begin{tabular}{ccc}
\hline $\begin{array}{c}\text { Jenis } \\
\text { Antibiotik }\end{array}$ & $\begin{array}{c}\text { Jumlah } \\
\text { Resep }\end{array}$ & $\begin{array}{c}\text { Persentasi } \\
(\%)\end{array}$ \\
\hline Seftriakson & 58 & 80,6 \\
Siprofloksasin & 6 & 8,3 \\
Sefotaksim & 5 & 6.9 \\
Sefazolin & 2 & 2,8 \\
Sefadroksil & 1 & 1,4 \\
\hline Total & 72 & 100 \\
\hline
\end{tabular}

Berdasarkan tabel 3 didapatkan data variasi peresepan beberapa golongan jenis antibiotik, berdasarkan data di dapatkan pemberian obat antibiotik Seftriakson menjadi yang paling sering di gunakan yaitu sebanyak 58 resep $(80,6 \%)$, Siprofloksasin sebanyak 6 resep $(8,3 \%)$, Sefotaksim 5 resep $(6,9 \%)$, Sefazolin 2 resep $(2,8 \%)$ dan Sefadroksil 1 resep $(1,4 \%)$.

Tabel 4 Distribusi Frekuensi Jenis Antibiotik dan Jumlah Dosis

\begin{tabular}{cccccc}
\hline Jenis Antibiotik & \multicolumn{3}{c}{ Jumlah Dosis } & Jumlah & Total (g) \\
\cline { 2 - 4 } & $2 \times 1$ & $1 \times 1$ & $3 \times 1$ & & \\
\hline Seftriakson & 58 & - & - & 58 & 1046 \\
Siprofloksasin & 6 & - & - & 6 & 16 \\
Sefotaksim & 4 & - & 1 & 5 & 20 \\
Sefazolin & 2 & - & - & 2 & 6 \\
Sefadroksil & 1 & - & - & 1 & 2 \\
\hline Total & 71 & - & 1 & 72 & 1090
\end{tabular}

Peneliti kembali akan mengelompokan pengggunaan antibiotik berdasarkan jenis antibiotik dan dosis yang di berikan yaitu seperti yang tertera pada tabel 4.6 yaitu jenis antibiotik Seftriakson menjadi yang tersering di berikan dengan jumlah 58 resep dengan dosis $2 \times 1$, diikuti oleh jenis antibiotik Siprofloksasin dengan jumlah 6 resep dengan dosis $2 \times 1$, jenis antibiotik Sefotaksim jumlah resep 4 dengan dosis $2 \times 1,1$ resep dengan dosis $3 \times 1$, jenis antibiotik Sefazolin jumlah resep 2 dengan dosis $2 \times 1$, dan yang terakhir jenis antibiotik Sefadroksil dengan jumlah resep 1 dengan dosis $2 \times 1$. Terlihat juga jumlah resep semua jenis antibiotik yaitu sebanyak 72 resep dan total penggunaan masing masing antibiotik dalam satuan gram yaitu Seftriakson 1046 gram, Siprofloksasin 16 gram, Sefotaksim 20 gram, Sefazolin 6 gram, dan Sefadroksil 2 gram. 
Tabel 5 Kuantitas penggunaan antibiotik dengan DDD/100 hari rawat inap

\begin{tabular}{ccccc}
\hline Jenis Antibiotik & EDosis (g) & DDD & $\begin{array}{c}\text { DDD/100 } \\
\text { hari rawat } \\
\text { inap }\end{array}$ & $\begin{array}{c}\text { Nilai } \\
\text { Standar DDD } \\
\text { WHO (g) }\end{array}$ \\
\hline $\begin{array}{c}\text { Seftriakson } \\
\text { Siprofloksasin }\end{array}$ & 1046 & 523 & 104,6 & 2 \\
Sefotaksim & 16 & 32 & 6,4 & 0.5 \\
Sefazolin & 6 & 5 & 1 & 4 \\
Sefadroksil & 2 & 0,6 & 0,4 & 3 \\
Total & 993 & 570,5 & 112,6 &
\end{tabular}

Berdasarkan tabel 5
kuantitas penggunaan antibiotik dihitung dengan menggunakan metode DDD (Defined Daily Dose) / 100 pasien untuk memperoleh data yang standar dan dapat dibandingkan dengan ruangan atau bangsal lain. Dari 72 pasien yang diberi antibiotik, didapatkan kuantitas pemberian Seftriakson adalah yang paling tinggi yaitu sebesar 104,6 DDD/100 patient days.

Karakteristik pasien menurut usia paling banyak adalah rentang usia 18-30 tahun, hal ini dikarnakan, pada pasien rawat rawat inap ruang Gelatik ini adalah pasien kecelekaan yang perlu penangan pembedahan, Menurut WHO 1,2 juta orang meninggal setiap tahunnya dalam kecelakaan lalu lintas dan 50 juta orang korban kecelakaan lalu lintas mengalami luka serius maupun cacat tetap, umumnya yang tewas dalam kecelakaan lalu lintas berusia 15-44 tahun dan $77 \%$ adalah laki-laki (WHO,2013).

Pada tabel 2 di atas memperlihatkan distribusi frekuensi lama rawat inap pasien dimana pasien dengan rentang lama rawat inap 6-10 hari dengan jumlah 31 pasien $(43,1 \%)$, ini sejalan dengan penelitian yang dilakukan oleh Nidianti tahun 2016 menyatakan bahwa lama rawat inap pada pasien pasca operasi bervariasi yaitu tujuh sampai tiga puluh hari dengan ratarata hari rawat inap antara tujuh sampai dengan empat belas hari. Lama perawatan yang memanjang disebabkan karena beberapa faktor, yaitu faktor ekstrinstik terdiri dari pemenuhan nutrisi yang tidak adekuat, teknik operasi, obat obatan, dan manajemen luka, sedangkan faktor intrinstik terdiri dari usia, gangguan sirkulasi, nyeri, dan penyakit penyerta. Pada tabel 3 di atas memperlihatkan distribusi frekuensi jumlah antibiotik yang telah diresepkan, terlihat bahwa antibiotik Seftriakson menjadi yang tersering di resepkan. Ceftriaxone merupakan antibiotik golongan cefalosporin generasi ketiga. Cefalosporin berasal dari fungus Cephalosporium acremonium yang diisolasi pada 9 tahun 1948 oleh Brotzu. Inti dasar Cefalosporin C ialah asam 7-amino-Sefalosporanat (7-ACA : 7-aminocephalosporanic acid) yang merupakan kompleks cincin dihidrotiazin dan cincin betalaktam. Cefalosporin generasi ketiga memiliki spektrum luas terhadap bakteri gram positif dan gram negatif tetapi kurang aktf dibandingkan dengan generasi pertama terhadap kokus Grampositif, tetapi jauh lebih aktif 
terhadap Enterobacteriaceae, termasuk strain penghasil penisilinase. Ceftriaxone memiliki waktu paruh yang cukup panjang sekitar 8 jam. Ketika ceftriaxone mencapai konsentrasi terapeutik, obat ini menunjukan penetrasi yang sangat baik ke jaringan - jaringan (Kemenkes, 2011).

Pada tabel 4 di sajikan data distribusi frekuensi penggunaan antibiotik dan dengan dosis penggunaannya. Dari data di atas dapat dilihat bahwa peresepan antibiotik dengan dosis $2 \times 1$ itu menjadi yang tersering seperti yang di lihat pada Tabel 4.4. Hal ini dikarnakan sediaan dosis pada jenis antibiotik itu berbeda, dan juga dosis maksimal harian nya pun berbeda. Setiap dokter yang meresepkan antibiotik tersebut pasti mempertimbangkan sediaan dosis antibiotik dan jumlah dosis harian yang dapat digunakan pada setiap pasiennya. Menurut WHO dosis maksimal harian pada jenis antibiotik Seftriakson itu 2 g/ Kg BB (gram) sedangkan sediaan dosis pada antibiotik Seftriakson itu adalah $1 \mathrm{G}$ (gram) ini yang menjadikan pemberian dosis $2 \times 1$ sehari dengan setiap pemberian $\begin{array}{llll}\text { maksimal } & 1 & G & \text { (gram). }\end{array}$ Pada tabel 5 kuantitas penggunaan antibiotik di RSUD DR. H. Abdul Moeloek Provinsi Lampung dalam satuan DDD/100 patient-days penggunaan antibiotik tertinggi di ruang Gelatik periode Januari-Maret tahun 2018 adalah Seftriakson. Perhitungan DDD/100 patient-days untuk Seftriakson pada tahun 2018 mencapai 104,6 DDD/100 patientdays menunjukkan bahwa terdapat 58 pasien mengkonsumsi 1 DDD/ 100 patient-days Seftriakson setiap harinya.

$\begin{array}{lr}\text { Penilaian } & \text { penggunaan } \\ \text { antibiotik secara } & \text { kuantitas } \\ \text { dilakukan dengan cara menghitung } \\ \text { DDD (Defined Daily Dose)/100 }\end{array}$

patient-days yang telah direkomendasikan oleh WHO. DDD / 100 patient-days merupakan unit pengukuran yang tidak tergantung pada harga dan formulasi obat akan tetapi suatu unit pengukuran independen yang mencerminkan dosis global yang terlepas dari variasi genetik, sehingga memungkinkan untuk menilai konsumsi obat dan membandingkan antar kelompok populasi atau sisitem pelayanan kesehatan. DDD / 100 patient-days diasumsikan sebagai dosis rata-rata pemeliharaan per hari untuk obat yang digunakan orang dewasa. Perlu ditekankan bahwa DDD / 100 patient-days adalah unit pengukuran dan tidak selalu sesuai dengan dosis harian yang direkomendasikan atau ditentukan (Prescribed Daily Dose). Salah satu komponen dalam DDD / 100 patient-days ini yaitu presentase dan perbandingan statistika konsumsi obat di tingkat nasional dan lainnya. Penggunaan satu macam/golongan obat dapat ditentukan bersifat berlebihan, sedang atau kurang dengan membandingkan pada tingkat konsumsi obat di suatu unit pelayanan kesehatan dengan yang lainnya(WHO,2012)

Selama periode JanuariMaret 2018, diperoleh total hari rawat inap (Length of Stay) dari 72 pasien adalah 484 hari yang ditunjukkan pada tabel 3. Total LOS pada penelitian ini digunakan pada perhitungan DDD / 100 patient-days sebagai pembagi dengan nilai standar DDD / 100 patient-days dari WHO. Berdasarkan rumusan dari metode DDD / 100 patient-days, nilai LOS berbanding terbalik dengan hasil nilai DDD / 100 patient-days yang akan didapat. Nilai DDD / 100 patient-days yang didapat akan semakin kecil apabila nilai total LOS semakin besar. Akan 
tetapi besarnya nilai LOS tidak selalu berarti nilai DDD / 100 patient-days akan lebih kecil dan sesuai dengan standar. Pada dasarnya, DDD / 100 patient-days adalah metode untuk mengkonversi dan menstandarisasi data kuantitas produk menjadi estimasi kasar penggunaan obat dalam klinik dan tidak menggambarkan penggunaan obat sesungguhnya(WHO, 2012) Kuantitas penggunaan antibiotik tertinggi di ruang Gelatik periode Januari-Maret tahun 2018 pada tabel 6 adalah Seftriakson. Perhitungan DDD/ 100 patient-days untuk Seftriakson pada tahun 2018 mencapai 104,6 DDD/100 patientdays menunjukkan bahwa terdapat 58 pasien mengkonsumsi 1 DDD/ 100 patient-days Seftriakson setiap harinya. Dari hasil penelitian ini peneliti menilai angka penggunaan antibiotik Seftriakson sendiri masih tinggi, bila dibandingkan dengan hasil penelitian yang dilakukan oleh Febiana, yang mendapatkan nilai DDD/100 patient-days 10,6 dengan antibiotik Seftriakson yang tertinggi. Di RSUD DR. H. Abdul Moeloek Provinsi Lampung tahun 2018 masih lebih tinggi dibandingkan dengan hasil penelitian Febiana (2012) di RSUP Dr. Kariadi Semarang Jawa Tengah. Seftriakson memiliki spektrum aktivitas yang luas dan efektif untuk pengobatan infeksi yang disebabkan oleh berbagai bakteri Gram positif dan Gram negatif. Mekanisme kerja Seftriakson sebagai antibiotik adalah dengan menghambat sintesa dinding sel mikroba melalui penghambatan kerja enzim transpeptidase tahap ketiga dalam rangkaian reaksi pembentukan dinding sel. Seperti generasi 3 golongan Sefalosporin lainnya (Sefotaksim,Sefatazidim), Seftriakso $\mathrm{n}$ kurang aktif terhadap beberapa bakteri aerobik Gram positif (misalnya, Staphylococcus) bila dibandingkan generasi yang pertama dan kedua, sehingga umumnya Seftriakson tidak dianjurkan untuk digunakan dalam pengobatan infeksi yang disebabkan oleh Staphylococcus. Seftriakson memiliki waktu paruh yang sangat panjang yaitu sekitar 8 jam sehingga dapat diberikan sekali sehari dan antibiotik ini efektif untuk diberikan sebagai profilaksis bedah pada pasien yang menjalani prosedur pembedahan dengan kelas bersih terkontaminasi . Penggunaan Seftriakson harus dilakukan monitoring karena bila penggunaanya berlebihan dapat menyebabkan terjadinya Methicillin-resisten Staphylococcus aureus (MRSA), dan dapat menjadi ancaman potensial dalam resistensi sehingga perlu meningkatkan kewaspadaan dalam pemilihan antibiotik profilaksis bedah (McEvoy, 2008).

Penelitian oleh Febiana tahun 2012 di bangsal anak RSUP Dr. Kariadi Semarang yaitu kuantitas penggunaan antibiotik, didapatkan kuantitas Seftriakson paling tinggi yaitu sebesar 10,6 DDD/ $100 \quad$ patient-days (Febiana,2012).

Hasil yang sama juga didapatkan dari penelitian yang dilakukan oleh Mahmudah yang dilakuakan di salah satu Rumah Sakit di Bandung pada tahun 2016 adalah, Menunjukan bahwa penggunaan Seftriakson paling banyak dibanding obat antibiotik yang lain (Mahmudah,2016). Adanya perhitungan sistem DDD/100 patient-days diharapkan penggunaan antibiotik di instalasi atau bangsal tertentu dapat dibandingkan dengan instalasi lain, bahkan antar rumah sakit atau antar negara sehingga dapat meningkatkan kualitas penggunaan antibiotik profilaksis tersebut. 
Penelitian ini memiliki beberapa keterbatasan, diantaranya yaitu peneliti tidak mengambil data diagnosis medis dengan lengkap dan hanya diambil data penggunaan antibiotiknya saja. Metode pendekatan yang digunakan yaitu retrospektif dimana metode ini memiliki kelemahan pada penulisan medik yang tidak lengkap. Penelitian ini merupakan penelitian pertama kali yang dilakukan di RSUD DR. H. Abdul Moeloek Provinsi Lampung. Hasil penelitian ini dapat digunakan sebagai bahan perbandingan tingkat konsumsi antibiotik di RSUD DR. H. Abdul Moeloek Provinsi Lampung dengan rumah sakit lainnya yang setara sehingga nantinya dapat ditentukan apakah penggunaan antibiotik dari hasil penelitian ini berlebihan, sedang, atau kurang, sehingga diharapkan pemberian antibiotik dapat memberikan hasil yang optimal.

\section{Ucapan Terima Kasih}

Penulis berterima kasih kepada semua staf rekam medic di RSUD Dr. H. Abdul Moeloek Provinsi Lampung, serta pembimbing di Universitas Malahayati Bandar Lampung.

\section{Pendanaan}

Penelitian ini dilakukan tanpa bantuan/hibah dari manapun.

\section{Konflik Kepentingan \\ Penelitian menyatakan tidak terdapat potensi konflik kepentingan dengan penelitian, penulisan dan atau publikasi artikel ini.}

\section{DAFTAR PUSTAKA}

Apriliana, W. (2017). Evaluasi Rasionalitas Pengggunaan Antibiotik Profilaksis Operasi Apendisitis Akut Pasien Dewasa dan Geriatri di RS Bethesda Yogyakarta 2015.

Brahma Marak and Wahlang. (2012). Rational Use of Drug and Irrational Drug Combination. The Internet Journal of Pharmacology, 10.

Ding, S., Lu, Q., Wang, F., Suqing, D., Qing, L., \& Feng, W. (2016). Rationale for Antibiotic Prescriptions in the Hospital: An Evaluation of Its Application and Administration Rationale for Antibiotic Prescriptions in the Hospital: An Evaluation of Its Application and Administration, 6176. https://doi.org/10.3109/23256 176.2013.797207

Ducel et al. (2002). Prevention of hospital-acquired infections World Health Organization.

Febiana, T. (2012). Kajian Rasionalitas Penggunaan Antibiotik di Bangsal Anak RSUP Dr. Karyadi Semarang Periode Agustus - Desember 2011. Semarang: Universitas Diponegoro

Lampert, M. L., Vogel, I., \& Mil, J. W. F. Van. (2017). Classification of drug- related problems with new prescriptions using a modified PCNE classification system, (March 2010). https: //doi.org/10.1007/s1109 6-010- 9377-x

McEvoy, K. G. (2004). AHFS Drug Information. Bethesda : America Socienty pd Healty System. Halaman 154 - 169

Soekidjo Notoatmodjo. (2015). Metodologi Penelitian Kesehatan

WHO. (2012). Raised Blood Pressure. Organisasi Kesehatan Dunia 